\title{
The Enduring test
}

\section{How long must you wait before proving your humanity?}

\section{Paul Levinson}

64 ow do I demonstrate my humanity to you?" Her blue eyes glittered. Her mouth grew taut. She looked vividly human, in every way.

"You cannot," I replied, carefully. Every word had to be well chosen. "Humanity is not something that can be demonstrated. It is rather something that is."

She sipped slowly from a cup of tea, regarded it, then placed it back on the table. "And what it is that makes an individual human? I presume you're not talking about a soul?"

I smiled. She was good. "I am not," I replied. "As far as I can tell, most people believe that possession of a soul is strictly in the eyes of the beholder."

"Very well," she said. "So we see things the same on the soul count. What else do you hold essential to the condition of humanity? Is it in the way that the DNA comes to be?"

"I doubt it," I replied. "What does it matter if DNA is spliced and sewn together, thread by thread, or emerges all at once from some unplanned shuffle of the chromosomes, if the result is the same? Anyway, DNA is a blueprint, a recipe. The truth of humanity is in the eating."

"Very nice," she said, and nodded her appreciation.

"Thank you," I replied.

"So what is it, then? Art?"

I shook my head no. "Painting by the numbers has been done since before there were personal computers."

"Music?"

"Not likely," I said. “Computers have been composing fine music for centuries. Mathematics and music have worlds in common."

"Then what? Sense of humour?"

"Try this," I replied. "A man is building a house. He has 25 bricks left. He completes the job with 24 . What does he do with the extra brick?"

\section{She shrugged. "I give up."}

"He throws it in the street," I said.

She looked at me for a long second. “That's not funny. I don't get it."

"No? Well, let me try another one on you. A man is smoking a big, foul-smelling cigar on a bus. He's seated next to a woman who has a poodle on her lap — shedding hair, and barking its head off. The two glare at each other. Finally, the woman, unable to contain herself, rips the cigar out of the man's mouth, and tosses it out the window. The man retaliates: he scoops up the little dog, and throws that out of the window. The two continue arguing, and get off at the next stop. As the bus pulls away, the poodle comes running up to the woman. It has something in its mouth. Know what it is?"

"The cigar?"

"No. The brick," I said.

She looked at me, then burst out laughing.

"So you see," I said. "It's not sense of humour either. You and I agree that the first - let us call it, sub-joke - was not funny. And the second, which fulfills the cycle, is at least worth a laugh."

She smiled again, then sighed. "So what is the essence of humanity? What is it that distinguishes you from me?"

"Have you heard of Alan Turing?" I asked.

"Of course," she replied. "The Turing test is hundreds of years old. If a non-human is indistinguishable from a human in the performance of its intelligence, then by what logic ought humans deny that the nonhuman has human intelligence?"

"Indeed," I said. "So, can you think of any such logic?"

She considered. "Well, we know that parrots do not really speak. Rather, they make sounds that mimic speech. And yet, according to the Turing test, one might listen to a parrot for a short time and conclude it was really speaking. But that can't be right. So there's something wrong with the test."

"Precisely!" I said. "Excellent. So, would you like to hear my addendum to the Turing test?"

Her eyes lit up. "I would."

"Well, I call it the Enduring test. It would go like this: if a non-human were indistinguishable from a human in the performance of its intelligence forever, then no one could deny that the non-human had human intelligence. This takes care of the parrot problem, you see, because even the cleverest parrot can only mimic for a brief time."

"Hmm..." she said. "Very good. I like that. But it seems a little extreme. Who could wait forever for the results of any test?"

"Yes, well, that's just the outer boundary, the ideal," I replied. "We could retreat to a lesser position and say, the longer a questionable entity was indistinguishable from a human in performance of intelligence, the less reason anyone would have for denying that such an entity had human intelligence. Would that work for you?"

She thought, then nodded her head slowly. "Yes, it might well. That's very good." She slowly pushed her chair back, and stood up. She extended her hand to me. "Thank you.

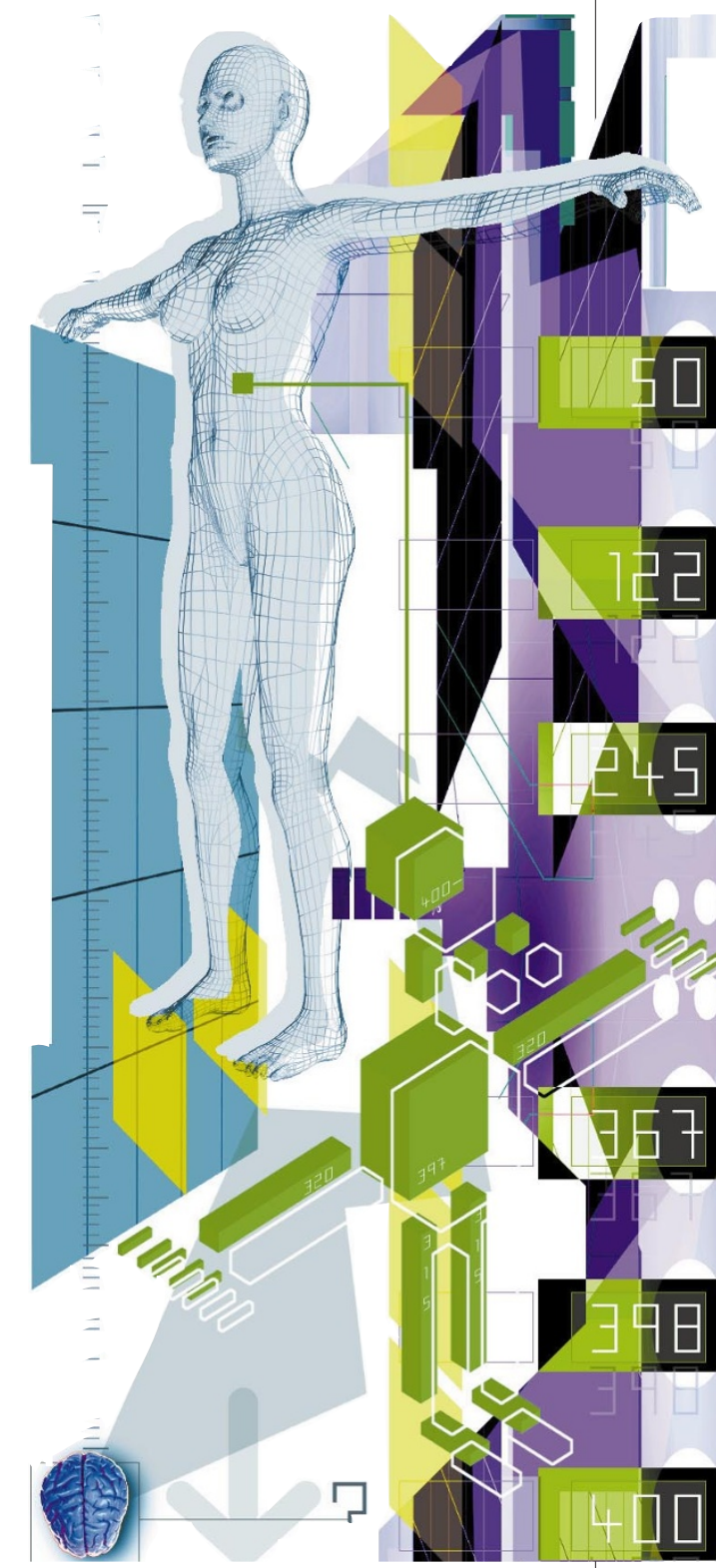

This conversation was very useful - one of the best yet. We'll be back to you on your application very shortly."

I looked at her through the window as she left. I very much wanted to be a school teacher. I could understand their reticence - their concern about leaving their children in even the temporary care of an artificial creation. Still, I knew I could do the job. I sighed. I guess I could last a hundred more years. That's what the specs said about my body and brain. But I didn't want to wait forever for their decision.

Paul Levinson's most recent books are the novel The Silk Code (Tor Books) and Digital McLuhan: A Guide to the Information Millennium (Routledge). 